\title{
DAKWAH PADA MASYARAKAT PEDESAAN DALAM BINGKAI PSIKOLOGI DAN STRATEGI DAKWAH
}

\author{
Ansori Hidayat \\ IAI Yayasan Nurul Islam, Jambi \\ Andrejulie2@gmail.com
}

\begin{abstract}
Society is a group of people who live together in a region and form a region and form a system, both semi-closed, where the interactions that occur in it are individuals who are in the group. Psychology is the science that studies or investigates human or animal behavior as seen by birth. The flow of behaviorism focuses its attention on outward behavior, because it is considered as a description of inner feelings or the soul. While the flow of sociology defines psychology as science that studies the process of human adaptation to the natural surroundings of $\mathrm{Da}$ 'wah that can be done in rural communities, namely the first, with the wisdom method, which is clear speech and is accompanied by propositions that reinforce the truth and eliminate doubts. Second, the oral method is a method through oral which is done in a way such as lectures, sermons, and others. Third, using the method of preaching is billatihiyaahsan is an approach that instills mutual respect between dai and mad'u. Fourth, by using the bil-hal method, it is da'wah with real deeds where the da'wah activities are carried out through role models and real charitable actions.
\end{abstract}

Keywoard: Society, Rural, Strategy, Psychology 


\section{A. Pendahuluan}

Kehidupan masyarakat saat ini mengalami perubahanperubahan yang sangat signifikan dalam hal aktifitas sosial keagamaan. Persoalan tersebut di sebabkan karena banyak sekali fakto-faktor sebagai salah satu pemicunya adalah media komunikasi yang telah datang mengguyur kehidupan masyarakat dengan berbagai ragam berita dan informasi melalui Smart Phone. Melalui Smart Phone berita fakta dan Fake news bahkan Hoax diterima oleh masyarakat.

Kegiatan dakwah saat ini harus lebih dinamis menyesuaikan kondisi mad'u atau masyarakat. Menggunakan bahasa yang persuasif,luwes adalah strategi yang harus di terapkan dalam kegiatan dakwah. Memahami situasi dan kondisi mad'u yang ada di masyarakat merupakan keharusan yang mutlak di ketahui oleh da'i, agar supaya pesan dakwah di dalam masyarakat lebih terkesan.

Al qu'ran Surat An-Nahl 125 telah memberikan pemahaman tentang bagaimana dakwah itu di lakukan dengan menggunakan teknik dan metode tersendiri

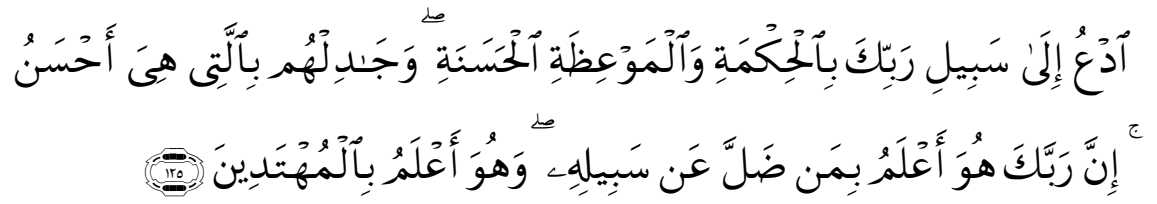

Artinya: Serulah (manusia) kepada jalan Tuhan-mu dengan hikmah dan pelajaran yang baik dan bantahlah mereka dengan cara yang baik. Sesungguhnya Tuhanmu Dialah yang lebih mengetahui tentang siapa yang tersesat dari jalan-Nya dan Dialah yang lebih mengetahui orang-orang yang mendapat petunjuk. (QS. An-Nahl: 125)

Dakwah islam adalah suatu aktivitas untuk merubah situasi dari yang kurang baik kepada yang lebih baik, sehingga terbentuk sebuah tatanan kehidupan keluarga (usrah), kelompok sosial (jama'ah), dan masyarakat (ummah) yang baik (kharu ummah), yaitu masyarakat yang terdiri dari individu-individu yang baik, berkualitas sesuai tuntunan Al-Qur'an dan Al-Hadits.

Untuk mewujudkan masyarakat yang islami (khairu Ummah), diperlukan dakwah islam yang tidak hanya dalam 
bentuk ajakan atau seruan dalam dakwah lisan semata, tetapi diperlukn sebuah gerakan yang berorientasi pada pengembangan masyarakat berupa pelayanan, bantuan sosial, dan pembinaansehingga terwujud kesejahteraan. Inilah yang difahami sebagai dakwah bil hal.Memahami konsep gerakan dakwah secara komprehensif, berarti problematika dakwah islam yang sedang kita jalani dan hadapi di masa-masa mendatang juga mencakup berbagai segi yang terkait dengan kehidupan manusia baik hubungannya dengan sesama makhluk Allah (Horizontal) maupun yang terkait dengan hubungan manusia dengan sang khalik (Vertikal).

Dakwah islam memerlukan setrategi baru yang mampu mengantisipasi perubahan zaman yang semakin dinamis. Oleh sebab itu dalam rekayasa peradaban islam sekarang ini untuk menyongsong kebangkitan umat di zaman modern diperlukan formasi strategi yang tepat.Strategi merupakan faktor yang sangat penting dalam berbagai hal guna mencapai tujuan yang telah ditetapkan. Strategi yang dirumuskan haruslah strategi yang betul-betul menawarkan alternative pemecahan, tidak hanya dalam konseptual, melainkan juga dalam dataran operasional.

Dalam upaya menunjang keberhasilan dakwah, seorang da'i dituntut untuk memiliki strategi yang bujak dan memiliki metode sebagai proses dalam pranata sosial dan kesadaran umat. Strategi menjadi sebuah keharusan untuk tercapainya suatu tujuan yang diinginkan, pada hakikatnya strategi merupakan serangkaian perencanaan untuk mencapain tujuan yang diinginkan, jika dikaitkan dengan proses dakwah, strategi mempunyai peran yang sangat penting bagi pergerkan kegiatan dakwah, seorang da'i dituntut untuk memiliki strategi dan metode untuk kesadaran umat.

\section{B. Pembahasan}

\section{Pengertian Psikologi}

Psikologi menurut bahasa berasal dari kata Yunani yang terdiri dari dua kata, psyche dan logos. Psyche berarti jiwa dan logos berarti ilmu. Jadi psikologi secara bahasa dapat berarti 'ilmu jiwa'. Namun pengertian ilmu jiwa itu sendiri masih dianggap kabur dan belum jelas, hal ini disebabkan 
karena para sarjana belum mempunyai kesepakatan tentang jiwa itu sendiri. Menurut Sarlito, tidak ada seorang pun yang tahu dengan sesungguhnya apa yang dimaksud dengan jiwa itu sendiri, karena jiwa adalah suatu kekuatan yang abstrak yang tidak tampak oleh panca indra, wujud, dan zatnya, melainkan yang tampak hanya gejala-gejalanya saja. ${ }^{1}$

Definisi psikologi juga telah mengalami proses dan perkembangan yang begitu panjang. Sebelum psikologi berdiri sendiri sebagai ilmu pengetahuan (science), para filsuf Yunani telah membahasnya dalam tema ilmu jiwa sebagai suatu gejala kejiwaan dalam bahasan mereka tentang filsafat dan ilmu faal. Para filsuf Yunani, seperti Plato dan Aristoteles yang hidup kira-kira 500 atau 600 tahun sebelum Masehi misalkan, mendefinisikan ilmu jiwa (psyche) sebagai ilmu pengetahuan yang mempelajari tentang hakikat jiwa serta prosesnya.

Menurut behaviorisme, psikologi adalah ilmu pengetahuan yang mempelajari atau menyelidiki tentang tingkah laku manusia atau binatang seperti yang tampak secara lahir. Aliran behaviorisme menitik beratkan perhatiannya pada tingkah laku lahirian, karena hal tersebut dianggap sebagai gambaran tentang perasaan batin atau jiwa. Sedangkan aliran sosiologi mendefinisikan psikologi sebagai ilmu pengetahuan yang mempelajari tentang proses adaptasi manusia dengan alam sekitarnya.

\section{Pengertian Dakwah}

Kata dakwah, bila ditinjau dari segi bahasa atau etimologi, berasal dari bahasa Arab, dalam bentuk isim masdar dari kata kerja "da'a- yad'u-da'watan ${ }^{2}$ yang berarti "panggilan, ajakan atau seruan, permohonan (doa). ${ }^{3}$ Apabila merujuk pada ayat-ayat al-Qur'an pada umumnya kata

${ }^{1}$ Faizah dan Muchsin Effendi, Psikologi dakwah, Jakarta: Kencana, 2006, h. 1-2

2 H. M. Alfandi, Strategi Dakwah Majilis Ulama Indonesia (MUI) di Tengah Arus Globalisasi dan Informasi, (Semarang: Lembaga Penelitian dan Pengabdian Masyarakat IAIN Walisongo, 2009), h. 19

3 Asmuni Syukir, Dasar-dasar Strategi Dakwah Islam, (Surabaya: AlIkhlas, 1983), h. 17 
dakwah memiliki pengertian mengajak kepada hal-hal yang bersifat baik (positif), namun demikina terdapat pula penggunaan kata dakwah dlam pengertian yang ditunjukan untuk hal-hal yang tidak baik (negatif) sebagaimana dijelaskan dalam penggalan QS. Al-Baqarah ayat 221. ${ }^{4}$

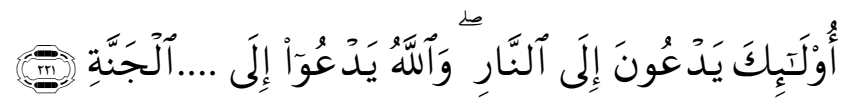

Artinya: "....mereka itu menyeru ke dalam neraka, sedang Allah menyeru ke dalam surga..." (QS. Al- Baqarah: 221).

Atas dasar itulah, dakwah dipahami mengandung dua pengertian. Pertama, dakwah sebagai seruan, ajakan, dan panggilan menuju kearah ketaatan dan kebajikan (menuju surga), dan kedua, dakwah sebagai seruan, ajakan dan panggilan menuju kemaksiatan dan kemungkaran (neraka). Dengan demikian dakwah secara etimologi (bahasa) adalah proses penyampaian pesan-pesan tertentu yang berupa ajakan atau seruan dengan tujuan agar orang lain memenuhi ajakan atau himbauan tersebut, baik himbauan atau ajakan yang bersifat positif dan negatif.

Sementara itu, secara istilah atau terminologi, dakwah yaitu setiap usaha yang mengarah pada perbaikan kehidupan yang lebih baik dan layak, sesuai dengan kehendak dan tuntunan kebenaran. Pendapat ini dapat dikatakan bahwa dakwah bukan hanya saja milik suatu agama atau golongan melainkan dakwah dimiliki oleh semua orang atau juga komunitas sehingga dapat menciptakan kehidupan yang damai, baik muslim, non Islam, masyarakat desa, kota ataupun suku yang terpencil atau terasingkan sekalipun. Dengan demikian, hakikat dakwah merupakan upaya mengajak manusia agar kembali kepada jalan Allah yakni mengikuti petunjuknya tanpa adanya paksaan, ancaman, tekanan atau kekerasan karena pada prinsipnya dakwah islam bersifat persuasif.

${ }^{4}$ Awaludin Pimay, Paradigma Dakwah Humanis: Strategi dan Metode Dakwah Prof. KH. Saifudin Zuhri, (Semarang: RaSAIL, 2005), h. 14 


\section{Dasar Hukum Dakwah}

Dakwah merupakan aktivitas menyeru manusia kepada agama yang dirdhoi oleh Allah swt. untuk alam semesta dan ajaran-ajaran yang telah diturunkan oleh Allah swt, wahyu atas rasulnya. Kewajiban berdakwah tercemin dari konsep amar ma'ruf nahi munkar, yakni perintah untuk mengajak masyarakat untuk meninggalkan atau menjauhkan dari perilaku kejahatan. Pijakan atau dasar dalam berdakawah adalah al-qur'an dan hadis.

1. Dasar Kewajiban Dakwah dalam Al-Qur'an

a. Surat An-Nahl ayat 125

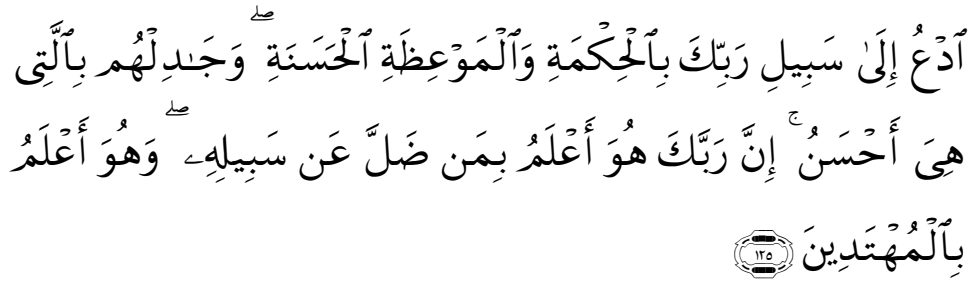

Artinya: "Serulah (manusia) kepada jalan Tuhan-mu dengan hikmah ${ }^{5}$ dan pelajaran yang baik dan bantahlah mereka dengan cara yang baik. Sesungguhnya Tuhanmu dialah yang lebih mengetahui tentang siapa yang tersesat dari jalanNya dan dialah yang lebih mengetahui orangorang yang mendapat petunjuk."

b. Surat Ali Imran ayat 104

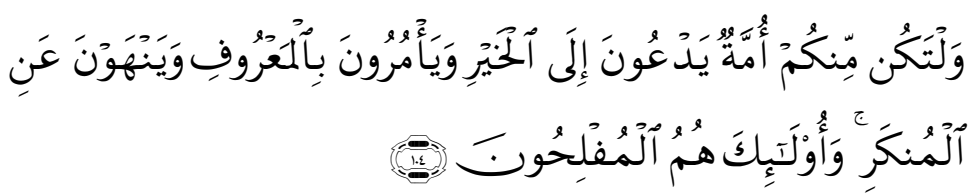

Artinya: "Dan hendaklah ada di antara kamu segolongan umat yang menyeru kepada kebajikan, menyuruh kepada yang ma'ruf dan mencegah dari yang munkar6; merekalah orang-orang yang beruntung."

5 Hikmah: ialah perkataan yang tegas dan benar yang dapat membedakan antara yang hak dengan yang bathil.

${ }^{6}$ Ma'ruf: segala perbuatan yang mendekatkan kita kepada Allah; sedangkan munkar ialah segala perbuatan yang menjauhkan kita dari pada-Nya. 


\section{Dasar Kewajiban Dakwah dalam Hadits}

Selain dalam al-quran dasar dakwah itu juga ada di hadits diaman mewajibkan umatnya untuk amar ma'ruf nahi munkar.

\section{a. Hadits Riwayat Iman Muslim}

Artinya: "Dari Abi Said al-Khudhariyi ra. Berkata: akau telah mendengar Rasullah bersabda: barang siapa diantara kamu melihat kemungkaran, maka hendaklah dia mencegah dengan tangan-tanganya (dengan kekuatan atau kekerasan), apabila ia tidak mampu dengan demikian (sebab tidak memiliki kekuatan dan kekuasaan); maka dengan lidahnya, dan jika (dengan lidahnya) tidak sanggup, maka cegahlah dengan hatinya, dan dengan yang demikian itu adalah selemah-lemahnya iman,: (HR. Muslim).

Hadits diatas menunjukan bahwa kemungkaran merupakan sesuatu yang sangat berbahaya. Untuk itu, kita diperintahkan untuk mencegah terjadinya kemungkaran. Selemah-lemahnya keadaan seseorang, setidak-tidaknya ia masih tetap berkewajiban menolak kemungkaran dengan hatinya, kalau ia masih tetap berkewajiban menolak kemungkaran dengan hatinya, kalau ia masih dianggap Allah sebagai orang yang masih memiliki iman, walaupun iman yang paling lemah. Penolakan kemungkaran dengan hati itu temapat bertahan yang minimal, benten penghabisan tempat berdiri.

\section{Pentingnya Dakwah Dalam Penyiaran Agama}

Dalam penyiaran suatu ajaran, agama, pemikiran apapun itu, tanpa adanya dakwah hal tersebut tidak akan berdiri tegak dengan begitu mudahnya. Terbukti melalui dakwah suatu agama atau ajaran belum tentu seratus persen diterima oleh masyarakat secara umumnya, namun setidaknya melalui dakwah suatu ajaran atau agama kemungkinan diterima lebih besar dari pada tanpa melalui dakwah. Dilihat dari sejarahnya Islam, dimulai dari awal Rosululloh mulai menyebarkan agama Islam secara sembunyi sembunyi,7 hingga zaman para wali di Indonesia, dakwah

7 Aminudin,Sanwar, Ilmu Dakwah, Semarang: Suatu pengantar Study, 2009, h. 30 
rupanya sukses menjadi media penyebaran agama Islam, terbukti dengan banyaknya umat muslim saat ini.

Dakwah sebagai cara menyampaikan suatu agama memang penting adanya, sejarahpun membuktikan dakwah sebagai cara penyebaran agama yang paling sukses dibandingkan perang yang lebih cenderung memaksa. Namun ada saatnya pula dakwah justru membawa pada keretakan yang berujung kehancuran, itu tergantung pada apa yang di dakwahkan, apakah itu tentang suatu hal yang membangun atau suatu pemikiran yang sengaja di sebarkan guna menjatuhkan dan menghancurkan seseorang atau suatu golongan.

Rosululloh saw bersabda "Barang siapa diantara kamu melihat kemungkaran, maka hendaklah ia merubah dengan tanganya, jika tidak kuasa maka dengan lisanya, jika tidak kuasa dengan lisannya maka dengan hatinya, yang demikian itu adalah selemah lemahnya iman" HR Muslim. Dari hadits ini didapat bahwa jika kita tidak mampu berdakwah atau menyampaikan sesuatu yang benar sesuai Al-quran dan sunnahnya jika tidak mampu dengan tindakan maka dengan ucapan, dan apabila dengan ucapan kita masih tidak sanggup maka gunakanlah hati sebagai tindakan terakhir untuk mendo'akanya.

\section{Pengertian Strategi Dakwah}

\section{Pengertian Strategi}

Strategi pada mulanya merupakan suatu istilah yang diadopsi dari kalangan militer, yang merujuk pada penggunaan dan pemanfaatan dana, daya dan peralatan perang serta siasat untuk memenangkan peperangan. Akan tetapi pada perkembangannya, istilah tersebut tidak hanya digunakan dalam bidang militer saja melainkan berkembang merambah ke berbagai bidang perkembangan seperti bidang manajemen, bidang politik, bidang ekonomi, bidang budaya, dan bidang dakwah, sehingga banyak ditemui istilah-istilah seperti: strategi komunikasi, strategi politik, dan istilah-istilah strategi lain tak terkecuali strategi dakwah. Secara etimologi, strategi berasal dari bahasa Yunani yaitu "stratos" yang berarti 
pasukan dan "again" yang berarti memimpin, sehingga setrategi dapat diartiakan sebagai hal memimpin pasukan. ${ }^{8}$

Strategi merupakan istilah yang sering diidentikkan dengan "taktik" yang secara bahasa dapat diartikan sebagai "corcerning the movement of organisms in respons to external stimulus" (suatu yang terkait dengan gerakan organisme dalam menjawab stimulus dari luar). Sementara itu secara konseptual strategi dapat dipahami sebagai suatu garis besar haluan dalam bertindak untuk mencapai sasaran yang telah ditentukan. ${ }^{9}$

Strategi juga dapat dipahami sebagai segala cara dan daya untuk menghadapi sasaran tertentu dalam kondisi tertentu agar memperoleh hasil yang diharapkan secara maksimal.10

\section{Pengertian Strategi Dakwah}

Strategi dakwah dapat diartikan sebagai proses menentukan cara dan daya upaya untuk menghadapi sasaran dakwah dalam situasi dan kondisi tertentu guna mencapai tujuan dakwah secara optimal. Dengan kata lain strategi dakwah adalah siasat, taktik atau manuver yang ditempuh dalam rangka mencapai tujuan dakwah.11

Berkaitan dengan stategi dakwah islam maka diperlukan pengenalan yang tepat dan akurat terhadap realitas hidup manusia yang secara aktual berlangsung dalam kehidupan dan mungkin realitas hidup antara satu masyarakat dengan masyarakat lain berbeda. Disini, juru dakwah dituntut memahami situasi dan kondisi masyarakat yang terus mengalami perubahan, baik secara

8 Ali Moertopo, Strategi Kebudayaan, Jakarta: Center For Strategic And International Studies, 1978, h. 8

9Pimay, Awaluddin, Paradikmah Dakwah Humanis: Strategi Dan Metode Dakwah Prof KH Syaifudin Zuhri, Semarang: Rasail, 2005, h. 50

10 Arifin M, Psikologi Dakwah Suatu Pengantar Studi, Jakarta: Bumi Aksara, 2003, h. 39

11 Pimay, Awaluddin, Paradikmah Dakwah Humanis: Strategi Dan Metode Dakwah Prof KH Syaifudin Zuhri, Semarang: Rasail, 2005, h. 50 
kultural maupun sosial keagamaan. Strategi dakwah semacam ini telah diperkenalkan dan dikembangkan oleh Rasulullah dalam menghadapi situasi dan kondisi masyarakat arab saat itu. Strategi dakwah Rasulullah yang dimaksud antara lain menggalang kekuatan di kalangan keluarga dekat dan tokoh kunci yang sangat berpengaruh dimasyarakat dengan jangkauan pemikiran yang sangat luas, melakukan hijrah ke Madinah untuk fath al-Makkah dengan damai tanpa kekerasan, dan lain sebaganya. ${ }^{12}$

\section{Pengertian Metode Dakwah}

Dakwah merupakan suatu proses upaya mengubah suatu situasi yang lebih baik sesuai ajaran islam atau proses mengajak manusia ke jalan Allah SWT yaitu Agama Islam. Para ulama memberi definisi sesuai pemikiran masingmasing sebagaimana di ungkapkan oleh Syekh Al-Babiy AlKhuli bahwa dakwah adalah upaya memindahkan situasi yang lebih baik. Pada prinsipnya, dakwah adalah kegiatan yang sifat menyeru, mengajak dan memanggil orang untuk beriman dan taat kepada Allah Subhaanahu wa ta'ala sesuai dengan garis aqidah, syari' at dan akhlak Islam. Kata dakwah merupakan masdar (kata benda) dari kata kerja da'a yad'u yang berarti panggilan, seruan atau ajakan.

Sementara kata "metode", dari aspek etimologi atau kebahasaan berasal dari dua kata, yaitu meta (melalui) dan hodos (jalan cara). Dalam bahasa Yunani kata "metode" berasal dari kata "methodos" artinya jalan. Metode disebut sebagai manhaj atau thariqat dalam bahasa Arab yang berarti tata cara, sedang dalam kamus bahasa Indonesia kata "metode" berarti cara yang teratur dan sigtimtis untuk pelaksanaan sesuatu: cara kerja (kamus ilmiah popular, Pius A Partanto, M. Dahlan Al-Barry, Arkola Surabaya). Jika digabungkan dengan kata "dakwah" maka metode dakwah yaitu cara-cara atau langkah-langkah sistematis dalam menyampaikan atau menyeru umat ke jalan Allah SWT sehingga dspat mencapai tujuan yang diinginkan.

12 Rafiuddin Dan Mannan Abdul Jalil, Prinsip dan Strategi Dakwah, Bandung: Pustaka Setia, 1997, h. 78 


\section{Bentuk-bentuk Metode Dakwah}
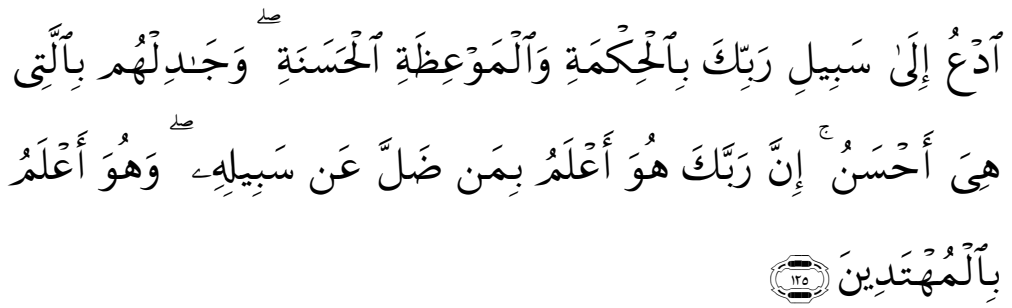

Artinya: "Serulah (manusia) kepada jalan Tuhan-mu dengan hikmah dan pelajaran yang baik dan bantallah mereka dengan cara yang baik. Sesungguhnya Tuhan-mu. Dialah yang lebih mengetahui tentang siapa yang tersesat dari jalan-Nya dan Dialah yang lebih mengetahui orang-orang yang mendapat petunjuk." (Q.S An-Nahl 16 ayat 125).

Dari ayat arti diatas dapat ditarik kesimpulan bahwa dakwah seyogyanya menggunakan cara-cara walau ayat diatas secara implicit tidak mengungkapkan metode-metode ilmiah sebagaimana dikaji dewasa ini. Didalam bagian ayat di atas disebutkan :"Seru dengan hikmah dan pelajaran yang baikBantah dengan caara yang baikTuhan lebih tahu kondisi keimanan manusia."

Selanjutnya akan dibahas metode-metode dakwah yang disusun oleh para pakar keilmuwan.

1. Metode Dakwah Al-Hikmah (Bi Al- Hikmah)

Dakwah bi al-hikmah merupakan suatu metode pendekatan komunikasi dakwah yang dilakukan atas dasar persuasif. Artinya dakwah disini dilakukan tanpa adanya paksaan. Kata "hikmah" bermakna arif dan bijaksanana.

2. Metode Dakwah Al-Mau'idzatil Hasanah

Kata Al- Mauidzatil Hasanah kerap melekat dalam pengajian-pengajian dan berbagai kegiatan keagamaan yang di dalam acara tersebut terdapat ceramah. Ceramah ini yang disebut sebagai, mauidzah hasanah dan mendapat porsi yang khusus sebagai acara yang "ditunggu-tunggu." 
Secara bahasa mauidzah hasanah terdiri dari dua kata bahasa Arab yakni, mauidzah dan hasanah. Mauidzah berarti nasehat, bimbingan, pendidikan, dan peringatan. Sedangkan Hasanah berarti baik, kebaikan. Maka secara terminology mau'idzah hasanah ialah nasihat atau peringatan yang membawa kebaikan.

a. Nasihat

Nasihat adalah cara yang bertujuan mengingatkan bahwa segala perbuatan pasti ada sangsi dan akibat. Secara terminology berarti memerintah atau melarang atau menganjurkan yang disertai dalil motivasi dan ancaman.

b. Tabsyir wa tanzir

Tabsir wa tanzir berasal dari dua kata berbahasa Arab, yang berarti memperhatikan/rasa senang dan peringatan. Tabsyir dalam istilah dakwah adalah penyampaian dakwah yang berisi kabar-kabar yang menggembirakan bagi orang-orang yang mengikuti dakwah.

c. Wasiat

Wasiat orang yang masih hidup kepada orang yang masih hidup. Dapat berupa ucapan, pelajaran atau arahan tentang suatu hal.

Wasiat orang yang meninggal (menjelang ajal) kepada orang yang masih hidup, berupa ucapan ataupun benda (harta waris).

3. Metode Dakwah Al-Mujadallah Bi Al-lati Hiya Ahsan

Secara etimologi atau kebahasaan Al-Mujadallh diambil dari kata bahasa arab Jadala yang artinya meminta, melilit. Dapat juga berarti berdebat, perdebatan. Kata Jadala dapat bermakna menarik tali guna menguatkan sesuatu.

\section{Aplikasi Metode Dakwah}

Dalam berdakwah dibutuhkan pendekatan-pendekatan agar pesan dakwah dapat tersampaikan dengan baik, serta berharap pesan dakwah dapat diterima dan diamalkan oleh penerima dakwah (mad'u).Dalam 
penyampaian pesan dakwah seorang dai memerlukan teknik penyampaian berupa pendekatan-pendekatan.

\section{Ayat-Ayat Dakwah dalam Al-Quran}

Beberapa ayat Di dalam Al-Quran yang menyeru untuk berdakwah diantaranya :

1. Al Imran ayat 104 dan 110

2. Al Nahl ayat 125

3. Al Qashaas 56 dan 87

4. Yusuf 108

5. $\mathrm{Al} \mathrm{Mu'minun73}$

6. At taubat 71

\section{Kode Eti Metode Dakwah}

Setiap hal harus memiliki batas etika. Begitu pula dengan dakwah. Batas-batas yang dimaksud merupakan ketetapan yang seharusnya diperhatikan oleh dai agar dakwah dapat berjalan sesuai harapan. Sebagaimna perilaku lain, dakwah mempunyai kode etik yang harus dijujung tinggi. Sumber rambu-rambu kode etik sorang dai ialah AlQuran, seperti yang telah dicontohkan oleh Nabi Muhammad.

\section{Karakteristik Kode Etik Dakwah}

Karakteristik yang dimaksud adalah dari etika islam itu sendiri, dimana cakupan dari sumber moral dakwah. Hal ini ditilik dari studi islam terbagi atas 3 bagian.

1. Bayani Tekstual

2. Burhani Dan airvani (akal dan naluri).

3. Motivasi Iman.

\section{Hikmah dalam Etika Berdakwah}

1. Kemajuan Rohani

2. Sebagai penunjuk Kebaikan

\section{Pengertian Masyarakat}

Masyarakat adalah suatu kelompok manusia yang hidup secara bersama-sama di suatu wilayah dan membentuk suatu wilayah dan membentuk sebuah sistem, 
baik semi tertutup, dimana intraksi yang terjadi di dalamnya adalah individu-individu yang ada di kelompok tersebut.

Secara etimologis kata " masyarakat" berasal dari bahasa arab, yaitu "musyarak" yang artinya hubungan (interaksi). Sehingga definisi masyarakat adalah suatu kelompok manusia yang hidup bersama-sama di suatu tempat dan saling berintraksi dalam komunitas yang teratur.

Suatu masyarakat terbentuk karena setiap manusia menggunakan perasaan, pemikiran dan hasratnya untuk beraksi terhadap lingkunganya. Hal tersebut menunjukan bahwa manusia adalah makhluk sosial yang secara kodrati saling membutuhkan satu sama lainya.

\section{Ciri-Ciri Masyarakat}

Suatu masyarkat dapat dikenali dar karakteristik yang ada didalamnya. Adapun ciri-ciri masyarakat adalah sebagai berikut:

1. Berada di wilayah tertentu

Mengacu pada pengertian masyarakat diatas, suatu kelompok masyarakat mendiami di suatu wilayah tertentu secara bersama-sama dan mewakili suatu sistem yang mengatur hubungi antar individu

2. Hidup secara berkelompok

Manusia adalah mahkluk sosial dan akan selalu membentuk kelompok berdasarkan kebutuhan bersama. Kelompok manusia ini akan semakin besar dan berubah menjadi suatu masyarakat yang saling tergantung satu sama lain.

3. Terdapat suatu kebudayaan

Suatu kebudayaan hanya dapat tecipta bila ada masyarakat. Oleh karena itu, sekelompok manusia yang telah hidup bersama dalam waktu tertentu akan melahirkan suatu kebudayaan yang selalu mengalami penyesuaian dan diwariskan secara turun-temurun.

4. Terjadi perubahan

Suatu masyarakat akan mengalami perubahan dari waktu kewaktu karena memang pada dasarnya masyarakat memilki 
sifat yang dinamis. Perubahan yang terjadi dimasyarakat akan disesuaikan dengan kebudayaan yang sebelumnya telah ada.

5. Terdapat iteraksi sosial

Interaksi sosial akan selalu terjadi didalam suatu masyarakat. Interaksi ini bisa terjadi bila individu-individu saling bertemu satu dengan yang lainnya.

6. Terdapat pemimpin

Aturan dan norma di butuhkan dlam suatu masyarakat agar kehifupan harmonis dapat terwujud. Untuk itu, maka dibutuhkan pemimpin untuk menindak lanjuti hal-hal yang telah di sepakati sehingga dapat berjalan sebagaimana mestinya.

7. Terdapat stratafikasisosial

Didalamnya masyarakat akan terbentuk golongan tertentu baik berdasarkan tugas dan tanggung jawab, maupun religius sitasnya. Dalam hal ini stratafikasi dilakukan dengan menempatkan individu pada posisi tertentu sesuai dengan keahlian dan kemampuannya.

\section{E. Macam-macam Masyarakat}

Secara umum, masyarakat dapat dibagi menjadi dua jenis, yaitu masyarakat primitif dan masyarakat moderen. Berikut penjelasanya:

1. Masyarakat primitive sederhana

Ini adalah jenis masyarakat yang di dalamnya belum terjadi perkembangan yang berarti dalam kehidupan mereka. Umumnya masyarakat ini masih terisolasi dan sangat jarang berinteraksi dengan masyarakat di luar komunitas mereka. adapun ciri-ciri masyarakat primitif/sederhana adalah sebagai berikut;

a. Mayarakatnya masih miskin ilmu dan harta

b. Masih berpatokan kepada budaya nenek moyang

c. Menolak budaya asing di dalam komunitasnya

d. Pemimpin dipilih berdasarkan garis keturunan

2. Masyarakat moderen

Ini adalah jenis masyarakat yang sudah mengenal ilmu pengetahuan dan teknologi terbaru, serta menggunakanya sehari-hari. Umumnya masyarakatnya sangat terbuka dengan 
hal-hal baru dan sering berinteraksi dengan masyarakat luar. Adapun ciri-ciri masyarakat moderen adalah sebagai berikut;

a. Masyarakat sangat terbuka dengan hal-hal baru.

b. Setiap individu di dalam masyarakat moderen sangat menghargai waktu.

\section{F. Tipologi Masyarakat Desa}

\section{Pengertian Tipologi}

Secara Umum Tipologi Masyarakat Dikategorikan Menjadi Dua, Masyarakat Tradisional Dan Masyarakat Yang Sudah Modern. Masyarakat Tradisional Adalah Masyarakat Yang Memiliki Solidaritas Yang Tinggi Dan Dalam Bentuk Solidaritas Mekanis Yaitu Hubungan Antara Individu Didasari Atas Kepentingan Bersama, Sedangkan Masyarakat Modern Adalah Masyarakat Yang Memiliki Solidaritas Yang Sangat Rendah Dan Dalam Bentuk Solidaritas Mekanis Yaitu Hubungan Antar Individunya Didasari Atas Kepentingan Individu Itu Sendiri. ${ }^{13}$

Tipologi Masyarakat Desa Dapat Dilihat Dari Tradisi Dan Kepercayaan, Kepemimpinan Dan Solidaritas Sosial Yang Ada Dalam Masyarakat (Weber, 2006). Masyarakat Desa Dalam Tindakannya Selalu Berorientasi Pada Hal-Hal Tradisi Dan Kepercayaan Atau Kebiasaan Bertindak Yang Terbentuk Dari Masa Lampau Dikategorikan Sebagai Masyarakat Yang Berorientasi Tradisional. Masyarakat Yang Berpedoman Kepada Rasionalitas Hukum Yang Disusun Secara Rasional Dalam Setiap Tindakan Sosial Dikatgorikan Sebagai Masyarakat Yang Berorientasi Rasional. ${ }^{14}$

Dalam Konteks Ini, Tipologi Desa Kota Sangat Relevan Untuk Mengkaji Lebih Mendalam Bagaimana Karakteristik Desa Kota Itu Sendiri. Pada Dasarnya Tipologi Merupakan Ilmu Yang Mengkaji Tentang Pengelompokan Berdasarkan Tipe Atau Jenis.Tipologi Dalam Konteks Desa Kota Dapat Menggolongkan Klasifikasi Sistem Kekerabatan, Hamparan Wilayah, Karakteristik, Dsb.Jadi Pada Dasarnya Tipologi Memberikan Informasi Tentang Pembagian Atau Pembedaan

${ }^{13}$ Alwisol.psikologi kepribadian(2006), malang. UMM press. h. 56

14 Yuliaty dan kurniasari tipologi masyarakat, (2014) ambon h. $9-15$ 
Jenis-Jenis Seperti Yang Disebutkan Diatas Tersebut Dengan Melihat Nilai-Nilai Dan Kultur Suatu Wilayah.

Dalam Konteks Ini, Tipologi Desa Kota Sangat Relevan Untuk Mengkaji Lebih Mendalam Bagaimana Karakteristik Desa Kota Itu Sendiri. Pada Dasarnya Tipologi Merupakan Ilmu Yang Mengkaji Tentang Pengelompokan Berdasarkan Tipe Atau Jenis. Tipologi Dalam Konteks Desa Kota Dapat Menggolongkan Klasifikasi Sistem Kekerabatan, Hamparan Wilayah, Karakteristik, Dsb.

Jadi Pada Dasarnya Tipologi Memberikan Informasi Tentang Pembagian Atau Pembedaan Jenis-Jenis Seperti Yang Disebutkan Diatas Tersebut Dengan Melihat Nilai-Nilai Dan Kultur Suatu Wilayah. ${ }^{15}$

\section{Pengertian Desa}

Desa Adalah Bentuk Pemerintahan Terkecil Yang Ada Di Negeri Ini. Luas Wilayah Desa Biasanya Tidak Terlalu Luas Dan Dihuni Oleh Sejumlah Keluarga. Mayoritas Penduduknya Bekerja Di Bidang Agraris Dan Tingkat Pendidikannya Cenderung Rendah. Karena Jumlah Penduduknya Tidak Begitu Banyak, Maka Biasanya Hubungan Kekerabatan Antarmasyarakatnya Terjalin Kuat. Para Masyarakatnya Juga Masih Percaya Dan Memegang Teguh Adat Dan Tradisi Yang Ditinggalkan Para Leluhur Mereka. ${ }^{16}$

Sedangkan Dalam UU Nomor 32 Tahun 2004 Disebutkan Pengertian Desa Sebagai Kesatuan Masyarakat Hukum Yang Memiliki Batas Wilayah, Yang Berwenang Untuk Mengatur Dan Mengurus Kepentingan Masyarakat Setempat, Berdasarkan Asal-Usul Dan Adat Istiadat Setempat Yang Diakui Dan Dihormati Dalam Sistem Pemerintahan Negara Kesatuan Republik Indonesia.(Alawiyah, Imamatul. 2013)

15 Soedjono, soekanto. Pengantar sosiologi.1982. Jakarta. h. 23

16 Bintarto. Interaksi desa kota dan permasalahanya. 1989. Jakarta. h. 214 


\section{Bagaimana Klasifikasi dan Tipologi Desa Kota}

Sistem tipologi di desa merupakan cara untuk mengenal desa-desa yang begitu banyak jumlah dan beragam bentuknya. dengan demikian, dapat di jelaskan secara detail setiap arah perkembangannya di indonesia. sistem klasifikasi dan tipologi desa didasarkan atas pendekatan ekosistem.

\section{G. Perilaku Keagamaan}

Sebelum membahas terlalu jauh tentang perilaku-perilaku keagamaan yangterjadi di masyarakat, ada baiknya perlu dijelaskan terlebih dahulu apa yangdimaksud dengan perilaku keagamaan. Sehingga pembahasan akan jauh lebihmendalam dan sistematis

\section{Perilaku}

Perilaku pengertian perilaku dalam kamus antropologi yaitu segala tindakan manusia yang disebabkan baik dorongan organisme, tuntutan lingkungan alam serta hasrat-hasrat kebudayaannya. ${ }^{17}$ Sedangkan prilaku di dalam kamus sosiologi sama degan "action" artinya "rangkaian atau tindakan". ${ }^{18}$

Perilaku menurut Hasan Langgulung adalah aktivitas yang dibuat oleh seseorang yang dapat disaksikan dalam kenyataan sehari-hari. ${ }^{19}$ Sedangkan menurut Bimo Walgito, perilaku adalah aktivitas yang ada pada individu atau organisasi yang tidak timbul dengan sendirinya, melainkan akibat dari stimulus yang diterima oleh organisasi yang bersangkutan baik stimulus eksternal maupun internal. Namun demikian sebagian terbesar dari perilaku organisme itu sebagai respon terhadap stimulus eksternal. Dengan demikian perilaku merupakan ekspresi dan manifestasi dari gejala-gejala hidup yang bersumber dari kemampuan-kemampuan psikis yang berpusat adanya kebutuhan, sehingga segala perilaku manusia diarahkan untuk memenuhi kebutuhan hidupnya sebagai mahkluk

${ }^{17}$ Ariyono Suyono, Kamus Antropologi (Jakarta: Akademik Persindo, 1985), h. 315

18Soerjono Soerkapto, Kamus Sosiologi (Jakarta: Rajawali, 1985), h. 7

${ }^{19}$ Hasan Langgulung, Teori-teori Kesehatan Mental (Jakarta: Alhusna, 1996), h. 21 
individu,mahkluk sosial, dan mahkluk berketuhanan. Jadi perilaku mengandung sebuah tanggapan atau reaksi individu yang terwujud dalam gerakan (sikap) bukan saja badan atau ucapan.

Dari beberapa teori di atas dapat disimpulkan bahwa perilaku merupakan indikasi seseorang dalam melakukan sesuatu perbuatan atau tindakan. Perilaku juga bisa terbentuk dari pengalaman seseorang dalam berinteraksi dengan lingkungan sekitar. Dengan adanya hubungan antara satu orang dengan orang yang lain akan menimbulkan berbagai macam perilaku sesuai dengan situasi yang dihadapi, misalnya seseorang akan menunjukkan perilaku tidak senangnya kepada lingkungan jika masyarakat tersebut selalu mengganggunya, dan perilakupun bisa mempengaruhi kehidupan keagamaan seseorang karena perilaku merupakan implikasi dariapa yang didapat dan dilihatnya dalam masyarakat dengan melakukan perbuatan yang diwujudkan dalam tingkah laku

\section{Keagamaan}

Keagamaan berasal dari kata agama, mendapat awalan "ke" dan akhiran "an", yang memiliki arti sesuatu (segala tindakan) yang berhubungan dengan agama. Agama berarti kepercayaan kepada Tuhan dengan ajaran kebaktian dan kewajiban-kewajiban yang bertalian dengankepercayaan itu.Dikatakan bahwa agama merupakan pengalaman batin yang bersifat individual dikala seseorang merasakan sesuatu yang ghaib, makadokumen pribadi dinilai dapat memberikan informasi yang lengkap, dan juga agama mengangkut masalah yang berkaitan dengan kehidupan batin yang sangat mendalam, maka masalah agama sulit untuk diteliti secara seksama, terlepas dari pengaruh subjektifitas. ${ }^{20}$

Lebih dari itu, agama adalah suatu jenis sosial yang dibuat oleh penganut-penganutnya yang berporos pada kekuatan nonempiris yang dipercayainya dan digunakan untuk mencapai keselamatan bagi diri mereka dan masyarakat luas umumnya.Dalam definisi tersebut di atas sangat terasa bahwa pada yang digunaan semata-mata ditunjukkan kepada

20 Suharso dan Ana Retnoningsih, Kamus Besar Bahasa Indonesia (Semarang: Widya Karya, 2011), h. 19 
kepentingan supra empiris saja. Seakan-akan orang yang beragama hanya mementingkan kebahagian akhirat danlupa akan kebutuhan mereka di dunia sekarang ini. Bagi Joachim Watch sebagaimana yang dikutip oleh HendroPuspito, aspek yang perlu diperhatikan khusus ialah pertama unsur teoritis.

\section{H. Rekayasa Sosial}

Rekayasa sosial merupakan cara untuk mengubah tatanan kondisi masyarakat yang menyimpang, slah, dan buruk menjadi kondisi masyarakat yang menyimpang, slah, dan buruk menjadi kondisi masyarakat yang terarah, benar,dan baik..$^{21}$

Rekayasa sosial dilihat dari susunan katanya, rekaya sosial/taghyir ijtima'i tersusun dari dua kata yaitu taghyir dan ijtima'i. Kata pertama, berarti perubahan dan kata kedua, berarti kemasyarakata, jadi kedua kata itu berarti perubahan sosial. Di dalam sosiologi, taghyir ijtima'i diucapkan dengan istilah perubahan sosial yang direncanakan, atau rekayasa sosial (social engineering).

Rekayasa sosial dilihat dari segi semantik, yaitu perpindahan dari suatu kondisi yang tidak diinginkan kepada kondisi lain yang di kehendaki. Perpindahan ini, tampaknya di atur oleh suatu hukum yang erat sekali hubunganya dengan target, sarana prasana dan sumber daya manusia. ${ }^{22}$

Dari penjelasan diatas dapat dipahami bahwa dalam melakukan perubahan kondisi masyarakat kearah yang lebih baik maka pelaku rekayasa sosialharus terlebih dahulu membuat perencanaan yang tepat. Rekayasa sosial dapat ditempuh dengan 2 tahapan yaitu yang pertama dengan tahap taghyir ma bi al-anfusihim (perubahan apa yang terdapat di dalam diri) berupa perubahan pemikiran, pemahaman,keyakinandan akhlak. Kedua, tahap taghyir ma biqaumin (perubahan kondisi sosial), berkaitan dengan muamalat, ekonomi, kemasyarakatan dan lainlain. Dengan tahapan tersebut bisa dilakukan dengan langkahlangkah yaitu mengidentifikasi bentuk kemungkaran terlebih

21 Muhammad Munir dan Wahyu Ilahi, Menejemen Dakwah, (Jakarta: Kencana, 2006), h. 253

22 Muhammad Munir dan Wahyu Ilahi, Menejemen Dakwah, (Jakarta: Kencana, 2006), h. 256 
dahulu, kedua menghitung-hitung kemampuan atau kekuatan, dan yang ketiga menentukan strategi dan metode yang digunakan dalam melaksanakan suatu perubahan. ${ }^{23}$

\section{Strategi Dakwah Islam untuk Masyarakat Pedasan dengan Psikologi Dakwah}

Stretegi dakwah sangat dibutuhkan dalam berdakwah di pedesaaan karena biasanya digunakan dalam membimbing, pengarahan dan pendampingan dalam mempelajari ajaranajaran Islam dengan berlandaskan al-qur'an dan hadits Rasullah, sehingga dapat menjalin kerjasama dengan organisasi-organisasi keagamaan (organisai Islam).

Menurut muhammad Ali Al bayuni berpendapat bahwa strategi dakwah dibagi dalam tiga bentuk, yaitu: (Muh. Ali, 2009: 351).

\section{a. Strategi Sentimentil (Al Manhaj Al-At hifi)}

Strategi sentimentil adalah dakwah yang memfokuskan aspek hati hati dan mengerakkan perasaan dan batin mitra dakwah. Memberi mitra dakwah nasehat yang mengesankan, memanggil dengan kelembutan, atau memberikan pelayanan yang memuaskan merupakan beberapa metode yang dikembangkan dari strategi ini.

b. Strategi Rasional (Al Manhaj Al-Aklii)

Strategi rasional adalah Dakwah dengan metode yang berfokuskan pada aspek akal, pikiran. Strategi ini mendorong mitra dakwah untuk berfikir, merenungkan dan mengambil pelajaran.

c. Strategi Indriawi Al Manhaj Al-Hisi

Strategi indriawi juga dapat dinamakan dengan strategi ilmiah. Ini di definisikan sebagai sistem dakwah atau kumpulan metode dakwah yang berorientasi pada panca indra dan berpegang teguh pada hasil peneliti dan percobaan. Metode yang di himpun oleh strategi ini adalah praktik keagamaaan, keteladanan, dan pentas drama.

${ }^{23}$ Muhammad Munir dan Wahyu Ilahi, Menejemen Dakwah, (Jakarta: Kencana, 2006), h. 258 
Selain strategi dakwah diatas ada strategi lain yaitu yang pertama, dengan metode hikmah yaitu ucapan yang jelas dan diiringi dalil-dalil yang mempertegas kebenaran dan menghilangkan keraguan. Metode ini menggunakan pendekatan langsung dengan dihadpkan kepada golongan pemikir atau kaum intelektual dengan mengetenngahkkan bukti-bukti ilmiah yang logis. Kedua, metode lisan yaitu metode melalui lisan yang dilakukan dengan cara seperti ceramah, khutbah, dan lain-lain. Ketiga, dengan menggunakan metode walmujadalah billati hiya ahsan merupakanpendekatan yang menanamkan rasa saling menghargai antara dai dan mad'u.Sehingga bisa memperkuat keyakinan seorang dai yang argumentatif, dan bahkan dapat mengalahkan argumentasi lawan bicara yang pada akhirnya dapat menerima apa yang diserukan oleh seorang dai. Keempat, dengan menggunakan metode bil-hal, merupakan dakwah dengan perbuatan nyata dimana aktifitas dakwah dilakukan melalui keteladanan dan tindakan amal nyata. ${ }^{24}$

Zaman sekarang komunitas muslim lebih mengkomparasikan beberapa metode dakwah yang digunakan dalam kegiatan dakwahnya. Namun dalam pelaksanaaanya lebih di dominasi dengan cara-cara tradisional. Sedangkan untuk metode dakwah modern belum mampu menggunakan atau memanfaatkanya. Dalam pengunaan media dakwah komunitas muskim masih menggunakan media massa baik cetajk maupun elektronik, lembaga-lembaga pendidikan, lingkungan keluarga maupun organisai-organisasi islam.

Dalam menafsirkan strategi dakwah dikalangan masyarakat perdesaan tidak dilihat dari segi strategi saja melainkan dilihat dari konsepsi dakwah, psikologi dakwahnya. Konsepsi masyarakat desa dan macam-macam strategi yang diterapkan menggambarkan bagaimana strategi dakwah yang akan direalisasikan pada masyarakat desa sesuai dengan kondisi yang di alami oleh masing-masing masyarakat.

\section{J. Kesimpulan}

Dalam menyusun strategi dakwah ternyata tidak semudah apa yang difikirkan. Strategi dakwah perlu memperhatikan

24 Samsul munir amin,rekontruksi pemikiran dakwah islam, (Jakarta: Amzah, 2008), h. 11 
aspek diantaranya masyarakat (mad'u), pesan, pendakwah (da'i) dan media yang digunakan dengan harapan materi dakwah yang disampaikan dapat diterima, mudah dimengerti, dipahami dan diamalkan. Selain itu pentingnya mempelajari strategi dalam dakwah agar mampu membuat masyarakat yang memberikan ataupun menerima informasi menjadi lebih paham akan strategi dakwah tersebut.

Strategi dakwah yang dapat dilakukan pada masyarakat pedesaan yaitu yang pertama, dengan metode hikmah yaitu ucapan yang jelas dan diiringi dalil-dalil yang mempertegas kebenaran dan menghilangkan keraguan. Kedua, metode lisan yaitu metode melalui lisan yang dilakukan dengan cara seperti ceramah, khutbah, dan lain-lain. Ketiga, dengan menggunakan metode walmujadalah billati hiya ahsan merupakan pendekatan yang menanamkan rasa saling menghargai antara dai dan mad'u. Keempat, dengan menggunakan metode bil-hal, merupakan dakwah dengan perbuatan nyata dimana aktifitas dakwah dilakukan melalui keteladanan dan tindakan amal nyata.

\section{Daftar Pustaka}

Awaludin Pimay, 2005 Paradigma Dakwah Humanis: Strategi dan Metode Dakwah Prof. KH. Saifudin Zuhri, (Semarang: RaSAIL)

Ali Moertopo, 1978 Strategi Kebudayaan, Jakarta: Center For Strategic And International Studies.

Alwisol 2006. Psikologi Kepribadian, Malang. UMM press.

Aminudin, Sanwar, 2009, Ilmu Dakwah, Semarang: Suatu pengantar Study.

Arifin M, 2003 Psikologi Dakwah Suatu Pengantar Studi, Jakarta: Bumi Aksara.

Ariyono Suyono, 1982Kamus Antropologi (Jakarta: Akademik Persindo,).

Asmuni Syukir, 1983 Dasar-dasar Strategi Dakwah Islam, (Surabaya: Al-Ikhlas).

Bintarto. 1982. Interaksi desa kota dan permasalahanya. Jakarta. 
Faizah dan Muchsin Effendi, 2006, Psikologi dakwah, Jakarta: Kencana.

H. M. Alfandi, 2009. Strategi Dakwah Majilis Ulama Indonesia (MUI) di Tengah Arus Globalisasi dan Informasi, (Semarang: Lembaga Penelitian dan Pengabdian Masyarakat IAIN Walisongo).

Hasan Langgulung, 1982 Teori-Teori Kesehatan Mental (Jakarta: Alhusna)

Muhammad Munir dan Wahyu Ilahi, 2006 Menejemen Dakwah, (Jakarta: Kencana)

Pimay, Awaluddin, 2005 Paradikmah Dakwah Humanis: Strategi dan Metode Dakwah Prof KH Syaifudin Zuhri, Semarang: Rasail.

Rafiuddin dan Mannan Abdul Jalil, 1997 Prinsip dan Strategi Dakwah, Bandung: Pustaka Setia.

Samsul munir amin, 2008 rekontruksi pemikiran dakwah islam, (Jakarta: Amzah)

Soedjono, 1982 soekanto. Pengantar sosiologi. Jakarta. Soerjono Soerkapto, 1982Kamus Sosiologi (Jakarta: Rajawali)

Suharso dan Ana Retnoningsih, 2011 Kamus Besar Bahasa Indonesia (Semarang: Widya Karya)

Yuliaty dan kurniasari, 2014 tipologi masyarakat, ambon. 